\title{
SOCIAL SECURITY SPOUSE AND SURVIVOR BENEFITS FOR THE MODERN FAMILY
}

\author{
Melissa M. Favreault and C. Eugene Steuerle* \\ CRR WP 2007-7 \\ Released: February 2007 \\ Draft Submitted: January 2007 \\ Center for Retirement Research at Boston College \\ Hovey House \\ 140 Commonwealth Avenue \\ Chestnut Hill, MA 02467 \\ Tel: 617-552-1762 Fax: 617-552-0191 \\ http://www.bc.edu/crr
}

* Melissa M. Favreault is a senior research associate at the Urban Institute. C. Eugene Steuerle is a senior fellow at the Urban Institute. The research reported herein was performed pursuant to a grant from the U.S. Social Security Administration (SSA) funded as part of the Retirement Research Consortium. The findings and conclusions are solely those of the authors and do not represent the views of SSA, any agency of the Federal Government, the Urban Institute, or Boston College. The authors thank Virginia Reno and Sheila Zedlewski for helpful comments.

(C) 2007, by Melissa M. Favreault and C. Eugene Steuerle. All rights reserved. Short sections of text, not to exceed two paragraphs, may be quoted without explicit permission provided that full credit, including $\left({ }^{\circ}\right.$ notice, is given to the source. 


\title{
About the Center for Retirement Research
}

The Center for Retirement Research at Boston College, part of a consortium that includes parallel centers at the University of Michigan and the National Bureau of Economic Research, was established in 1998 through a grant from the Social Security Administration. The Center's mission is to produce first-class research and forge a strong link between the academic community and decision makers in the public and private sectors around an issue of critical importance to the nation's future. To achieve this mission, the Center sponsors a wide variety of research projects, transmits new findings to a broad audience, trains new scholars, and broadens access to valuable data sources.

\author{
Center for Retirement Research at Boston College \\ Hovey House \\ 140 Commonwealth Avenue \\ Chestnut Hill, MA 02467 \\ phone: 617-552-1762 fax: 617-552-0191 \\ e-mail: crr@bc.edu \\ www.bc.edu/crr
}

\author{
Affiliated Institutions: \\ American Enterprise Institute \\ The Brookings Institution \\ Center for Strategic and International Studies \\ Massachusetts Institute of Technology \\ Syracuse University \\ Urban Institute
}




\begin{abstract}
Our project uses DYNASIM3, the Urban Institute's dynamic microsimulation model of the U.S. population, to simulate several alternative systems of Social Security auxiliary benefits. We specifically consider earnings sharing, a system in which a husband's and a wife's earnings records are combined and averaged over the duration of their marriage when computing Social Security benefits. We also consider whether other changes to Social Security’s benefit computations - like caregiver credits, minimum benefits, and more modest changes to spouse/survivor benefits - could improve program adequacy and horizontal equity with less complexity and fewer transition difficulties relative to earnings sharing. Each proposal we examine substitutes existing spouse (and, sometimes, all or parts of survivor) benefits with mechanisms that explicitly acknowledge marital partnerships, are more neutral with respect to marriage, and/or better target economically vulnerable people. All proposals are roughly cost-equivalent in 2050 . We find that all three packages - earnings sharing, replacement of most of the spouse benefit with a minimum, and full spouse replacement with caregiver credits - reduced poverty modestly and made lifetime benefits more similar for couples paying the same amount in taxes relative to current law scheduled. The earnings-sharing proposal, however, only achieved the poverty reduction with significant adjustments to the treatment of surviving spouses through a self-financed survivor benefit. The packages reveal important tradeoffs among beneficiary groups, with particular tensions between workers and non-workers, and married, never married, divorced, and widowed persons.
\end{abstract}




\section{Introduction}

Women’s family lives have changed enormously over the past few decades, and these shifts have had important implications for their economic security in old age. Most women work outside of the home, even when their children are quite young (Dye 2005). ${ }^{1}$ Women are less likely to marry, and when they do, divorce is common. ${ }^{2}$ Remarriage is becoming less common for those who divorce. In January of 2007, the New York Times drew national attention to these trends when it reported that in 2005 over half of adult women did not live with a spouse (Roberts 2007). Over a third of all U.S. children are now born to unmarried women. The implications of such trends for retirement security are sobering: aged poverty rates are very high for unmarried women (Social Security Administration 2006), and women who have raised children outside of marriage are especially vulnerable (Johnson and Favreault 2004).

In the 1980s, many advocates proposed earnings sharing within Social Security as a means for addressing the ways that women's changing family roles would impact their retirement security. (By earnings sharing, we refer to plans in which a husband's and a wife's earnings records are combined and averaged over the duration of their marriage for the purposes of computing Social Security benefits. Typically this occurs in concert with reductions in — or elimination of - the program's spouse and survivor benefits.) They particularly sought to improve the status of the increasing number of divorced women entering middle life and retirement age (Butrica and Iams 2000). Such proposals also sought to address inequities in Social Security's current law benefit structure that advantage single-earner families relative to dual-earner families who pay the same amount in taxes. These proposals had a lot of appeal and resonance, given their complementarities with notions of marriage as a partnership in which spouses should fully share both incomes and obligations.

Analysts extensively examined possible consequences of earnings sharing alternatives in this period, including simulating dozens of alternative parameterizations (e.g., Congressional Budget Office 1986). Such proposals never gained sufficient political traction because of their

\footnotetext{
${ }^{1}$ At present, about half of women who have given birth within the past year are working, with over a third working full time (Dye 2005). Among those who last gave birth 3 to 5 years ago, this increases to 63 percent, with 47 percent working full time. Socioeconomic differentials in work among mothers who have recently had a child are substantial, with more educated and black mothers quicker to return to work than mothers who are less educated, Hispanic, or white.

${ }^{2}$ While U.S. divorce rates did level off in the 1980s, international experience suggests that a further retreat from formal marriage (for example in favor of extended non-marital cohabitation) is possible in the future.
} 
difficult implementation and some of their (often unanticipated) distributional consequences. Ross and Upp (1993) concluded that the main reasons why these earnings sharing proposals eventually failed were inherent conflicts in the competing objectives, unintended consequences, costs, and lengthy transition periods. Surprisingly, more recent OASDI reform discussions have devoted proportionately less attention to the family benefits that the system provides, despite continuing and rapid changes in U.S. family life. In debates over personal accounts, many did mention the possible importance of earnings sharing for account balances, especially in the context of divorce (see, for example, Reno et al. 2005). These debates did not, however, typically extend to the context of updating the traditional system.

In this paper, we consider whether earnings sharing in Social Security may be worth another look. Changes over the past few decades may have alleviated some of the challenges to earnings sharing previously identified (e.g., transition periods may now be shorter, reducing costs). It is also possible that society has changed so much, with later and less frequent marriage (and remarriage), that the idea has simply passed its usefulness. We also consider whether other changes to Social Security’s benefit computations, including features like caregiver credits, minimum benefits, and more modest changes to the spouse/survivor benefits, could similarly improve Social Security adequacy and horizontal equity, but without introducing the same level of complexity and transition difficulties as earnings sharing. Each proposal we examine entails substituting existing spouse (and, sometimes, all or parts of the survivor) benefits with mechanisms that are more explicit in acknowledging marital partnerships, more neutral with respect to marriage, and/or better targeted toward people who are economically vulnerable.

The packages of Social Security proposals that we examine are all approximately costequivalent in 2050. Our objective is to present three types of systems that spend roughly the same amount as current law but improve Social Security’s performance along a set of criteria including poverty reduction, more equitable treatment of individuals/couples who pay the same amount of Social Security payroll tax, and increasing work incentives. We use scheduled benefits as the base for comparison, but roughly equivalent qualitative results apply to systems with reduced benefits under reform. Our project uses DYNASIM3, the Urban Institute’s dynamic microsimulation model of the U.S. population. To evaluate the three alternative systems, we compute alternative outcome measures that reflect the system's performance along various adequacy, efficiency, and equity criteria, both cross-sectionally and over a lifetime. 
We organize our paper as follows. First, we provide some background on Social Security law and benefit distributions, and discuss the concerns with current auxiliary benefit payment structures that prompted the earnings sharing debate. In this section, we set out some criteria for reform of OASDI auxiliary benefits based on principles. We then describe literature that has addressed such reforms, and identify the strengths and weaknesses that researchers have found for various approaches. We next turn to parameterizations of our simulations, and briefly discuss our methods. The results from the options follow. Finally we turn to our conclusions and provide some initial speculation on their policy implications. We find that several parameter combinations would render Social Security more effective at reducing poverty and would treat spouses paying the same amount in taxes more similarly relative to current law, including some variants of earnings sharing plans. However, the distributional properties of the reforms vary substantially, and, as with all expenditure and tax reforms, there are losers as well as winners. This suggests that policymakers need to carefully weigh competing objectives and interests.

\section{Background and Criteria for Reform}

Description of the law: Social Security awards a significant fraction of its benefits to the spouses and survivors of retired, disabled, and deceased workers. A worker's spouse is entitled to a Social Security benefit equal to half the worker's Primary Insurance Amount (PIA) while he or she is still alive, and 100 percent of the PIA after his/her death. ${ }^{3}$ The worker does not pay any additional payroll tax for this added protection. ${ }^{4}$ Spouses with their own work histories receive the higher of their own benefit or the spouse/survivor benefit. A person who has a qualifying work history but receives a higher benefit as a spouse or survivor is referred to as dually entitled. The benefit that he/she could receive based on his/her earnings is considered a worker benefit, and then the "top up" of the benefit is considered a spouse or survivor benefit. Divorced workers whose marriages lasted at least 10 years can also receive spousal/survivor benefits, with special rules applying when a worker has been married more than once. ${ }^{5}$

\footnotetext{
${ }^{3}$ Actuarial reductions apply if workers/spouses claim benefits before the normal retirement age, with different size reductions for workers and spouses, and delayed retirement credits apply if they collect benefits after the full retirement age.

${ }^{4}$ In private pension systems, in contrast, workers often take benefit reductions to finance spouse/survivor coverage.

${ }^{5}$ When a person has been married multiple times, he or she can usually receive a spousal benefit based only on the current marriage (if the current marriage started before one turned age 60). If one is not currently married, then one can usually collect benefits based on the highest-earning of one's former spouses from qualifying marriages. (See Social Security Administration 2007 for additional information on these and other OASDI regulations.)
} 
The extent to which Social Security benefits change before and after a spouse's death can vary because of these regulations. If a worker's spouse has not worked or is a dual entitlee (and so the family receives a spousal benefit or combined spouse/worker benefit rather than a second worker-only benefit), family income drops by one third upon widowhood of the lower earner (from one and a half times PIA to one times PIA). When both spouses are workers, the family income can drop by more, as much as fifty percent if the spouses' earnings are equal (from two times PIA to one times PIA), when the first spouse dies.

Rationale: The principle justification for Social Security's spousal support subsidy is one of replacement of adequate family, rather than just individual, income upon a workers' disability, death, or retirement. Social insurance allows workers to pool their risks of becoming disabled or living an exceptionally long life (and thus outliving their economic resources). As part of this package, auxiliary benefits contributed to the dramatic improvement in aged economic wellbeing since Social Security started paying benefits in the late 1930s.

A key philosophical question is whether contributors to this social insurance program should pay extra payroll tax for added protection for their spouses/survivors. Earlier in the program's history, aged poverty was widespread, especially among widows, and women's rates of work outside the home were relatively low. This made the case for subsidized spousal coverage relatively non-controversial. At present, however, the aged are far less likely to be poor than children, and about as likely to be poor as prime-aged adults (DeNavas-Walt, Proctor, and Lee 2006). Just over half of all households (and about 68 percent of families with children) are made up of married couples, and those households with two married people typically have two earners. These patterns make it less clear that married families with single earners warrant special protection at no extra cost (and thus implicit subsidies from others participating in the system). ${ }^{6}$

Another perspective is that the present system, by basing benefits on an ex-spouse's entire work history, provides a form of divorce insurance in retirement (though of course only for those married for at least ten years). Because a person can greatly reduce his/her long-term earnings capacity by taking off time to care for children, he/she is taking a significant economic risk, both for later career and retirement when doing so. Again, the question arises to whether

\footnotetext{
${ }^{6}$ This is in contrast to disability and dependent children's insurance, where the case is more compelling that those at higher risk should not have to pay higher rates.
} 
people who have not married (and never will) should be required to pay for divorce insurance from which they are ineligible to benefit, or whether the divorcing spouses should finance most of this type of protection themselves (for example, through higher earning spouses compensating lower earning spouses, either in an explicit OASDI formula or in settlements in the courts). Similar issues arise for couples that do not divorce, but where a higher-earning spouse may not make provisions that adequately account for the lower-earning spouse's economic well-being if he/she (the higher-earner) dies first.

Concerns with the current system: Analysts have expressed concern about the ability of Social Security's system of spouse and survivor benefits to continue to limit poverty among the elderly, while treating different groups of beneficiaries equitably as American families change. With more people electing never to marry, high divorce rates, and more married women in the labor force, the mismatch between OASDI payment structures - clearly rooted in the archetype of a traditional family, with a sole breadwinner and a stay-at-home homemaker — and the organization of American family life is ever more striking. The equity, adequacy, and efficiency problems of Social Security auxiliary benefits as currently designed are well known and have been extensively documented elsewhere (see, for example, U.S. Department of Health, Education, and Welfare 1979, Holden 1979, Burkhauser and Holden 1982, Ferber 1993, Favreault, Sammartino, and Steuerle 2002), so we provide only a brief summary here.

One particular concern is that auxiliary benefits depend on one's marital history and a worker's lifetime earnings, rather than on a spouse/survivor's need. Spouses of workers with higher earnings receive higher supplements than spouses of workers with lower earnings, and can even receive higher benefits than some workers. As a consequence, and because workers do not pay additional payroll tax for these benefits, the system can implicitly mandate transfers from people who are less well off (single low- and middle-wage workers) to those who are better off (spouses/survivors of high wage workers). (All else equal, groups that pay payroll taxes but are ineligible to receive auxiliary benefits implicitly subsidize others' benefits.) This occurs without regard to whether such persons have raised children, as spouse/survivor benefit eligibility depends on legal marital status, not on whether one has raised children with the spouse. ${ }^{7}$

\footnotetext{
${ }^{7}$ In states that recognize common law marriage, such marriages allow one to qualify for Social Security spouse or survivor benefits. Even if a state recognizes gay marriage, such marriages do not qualify because of provisions of the Defense of Marriage Act (1996).
} 
Further, the system often grants far higher lifetime benefits - on the order of tens and sometimes even hundreds of thousands of dollars - to couples in which spouses earn very different amounts than to couples in which spouses earn similar amounts, even when both couples pay the same amount in payroll taxes and the couple with different earnings levels typically has more time for leisure and household production (because one spouse did not work, or works significantly fewer hours, for example). As already noted, survivors in families with more similar earnings also frequently experience much steeper reductions in Social Security upon the death of a spouse.

Because of the high correlation between marriage and divorce patterns with race and socioeconomic status, another concern is that Social Security spouse and survivor benefits can serve to exacerbate inequities by race, lifetime earnings, and education. Literature has clearly shown that disproportionate fractions of spouse and survivor benefits go to whites (relative to blacks and Hispanics), and projections suggest that this trend should worsen in coming decades (Harrington Meyer 1996, Ozawa and Kim 2001, Harrington Meyer, Wolf, and Himes 2004).

OASDI's system of auxiliary benefits also creates many anomalies surrounding marriage and timing of marriage/divorce (Steuerle 1999). These include the following examples:

- "Cliffs" in OASDI eligibility due to the ten-year marriage duration requirement;

- Steep remarriage penalties for lower earnings spouses whose spouses have died that may suppress remarriage (Brien, Dickert-Conlin, and Weaver 2004);

- Enormous marriage bonuses for some persons with multiple marriages;

- Divorced spouses who are better off when their ex-spouses are dead (when they become eligible for 100 percent of the ex's PIA) than when the exes are alive (when they are eligible for 50 percent of the PIA);

- Variable redistribution based on spouse age differences, with those with older spouses potentially benefiting more from survivor benefits than those with younger spouses.

For many families, the current Social Security system has poor work incentives. Because they are entitled to higher benefits on their spouses' records than on their own, many secondary earners have extremely high marginal tax rates and/or receive no return on their additional payroll tax contributions (Feldstein and Samwick 1992).

Finally, and perhaps most importantly, the current system does not provide an adequate income to all beneficiaries and their families. Poverty in retirement remains a big issue for women (and some low-income men). Women's elevated poverty risk stems in large part from the fact that they live longer than men. They also tend to work at lower wages, and take more years out of the work force (for example to care for children or aging parents). Women are particularly 
vulnerable to falling into poverty at divorce or at a spouse's death, though accurately capturing such transitions to poverty raises measurement issues (Burkhauser, Holden, and Myers 1986).

Magnitude of equity problem, past, present and future: Because increasing fractions of women have earnings histories, some of the anomalies associated with couples with different earnings shares have been reduced compared to a few decades ago. ${ }^{8}$ Sizable issues nonetheless remain, especially among survivors. Benefits that are based solely on marriage to a qualified worker (rather than one’s own work history) now comprise just under 20 percent of aggregate Social Security benefits to adults. ${ }^{9}$ Figure 1 breaks down the aggregate fraction of adult OASDI benefits into earned and auxiliary types. Workers, either retired or disabled, receive just over 80 percent of total benefits. (This estimate includes benefits for both retired and disabled workers, as well as the earned portions of dual entitlees’ benefits.) Workers' survivors (overwhelmingly women because of male-female life expectancy differentials, coupled with the fact that men on average marry women who are younger than themselves) receive the next largest fraction about ten percent of the total. Dually entitled survivors — survivors with work histories (typically of at least ten years) — receive nearly five percent of adult benefits. "Pure” spousal benefits and benefit top ups for dually entitled spouses comprise the remaining five percent of benefits to adults.

If we break these figures down further by age, we do see that the largest non-working group ("pure” survivors) is disproportionately made up of older women (Social Security Administration 2007: Table 5.A15). As new cohorts of women enter retirement, we would anticipate that the fraction receiving survivor only benefits will decline, reducing horizontal inequities between working and non-working wives from this source. Projections from DYNASIM indicate that within a few decades, the fraction of aggregate benefits that are worker/worker portions will increase from the 80 percent level we currently observe to closer to 90 percent. So we expect significant reductions in unearned benefit fractions among adults, but that an important percentage of total OASDI will continue to be directed to non-working adults, who may be less economically vulnerable than some of their working counterparts.

\footnotetext{
${ }^{8}$ For example, throughout the 1950s and 1960s, less than 10 percent of aged women receiving spouse and survivor benefits were also entitled as workers, compared to 51.4 percent of wives and 44.9 percent of widows who were dually entitled in 2005 (Social Security Administration 2007: Table 5.G2).

${ }^{9}$ We exclude disabled adult children ("DACs") from these calculations.
} 
Magnitude of adequacy problem: Poverty estimates reveal that women are still at high risk of being poor or near poor in retirement. About 12 percent of women ages 65 and older were poor in 2004, compared to 7 percent of men (Social Security Administration 2006). Women who were nearly poor (defined as having income of less than 125 percent of poverty) approached 20 percent, compared to just over 12 percent for men. Unmarried women are almost four times more likely to be poor than married women (17.4 vs. 4.4 percent). Within this group, never married and divorced women are worse off than widows, with respective poverty rates of 21.3, 20.7, and 15.4 percent and near poverty rates of 27.9, 30.0, and 26.9.

Criteria for reform: Given these very compelling and sizable inequities and adequacy gaps, especially among unmarried women, we propose several criteria for evaluating reforms to Social Security to improve the design of adult auxiliary benefits. These criteria, based on principles of equity and efficiency, were prominent in previous examinations of earnings sharing. We suggest that proposals in this area should meet at least some (and ideally all) of the following objectives:

- Reduce poverty and near poverty among beneficiaries;

- Equalize the lifetime benefits of individuals (or couples) who pay the same amount of payroll tax;

- Ensure that lower earners in a couple are protected at divorce and that entitlement to benefits is portable at divorce;

- Introduce closer ties to childbearing than to marriage;

- Reward work, so that additional work always results in higher OASDI benefits;

- Avoid creating marriage disincentives.

\section{What are the ways one could deal with the problem, and what does past research say about them?}

An extensive literature addresses how Social Security spouse and survivor benefits shape program adequacy and equity by gender, marital status, and family earnings patterns. Over the years, there have been tensions between several different approaches for addressing some of the system's limitations. Some analysts propose incremental changes that leave the basic relationships in Social Security law in tact, but alter certain parameters to achieve better distributional results (for example, changing computation years, the percentage of PIA that a spouse or survivor receives, or parameters in the special minimum benefit). Others have proposed a move toward a two-tiered system, in which universal benefits would offer a floor of protection to all, with a smaller earnings-related portion. A third group has suggested earnings 
sharing. Table 1 provides a summary of selected proposals geared at improving the program's performance that have been prominent in recent decades. The table lists how the literature has indicated these proposals are likely to perform along the various criteria that we have just enumerated (with the caveat that the proposals are rarely compared assuming equivalent expenditures).

Throughout the 1980s, a period of significant debate and research in this area, earnings sharing was much of the focus (see, for example, Burkhauser and Holden 1982, Congressional Budget Office 1986). Summarizing research results on earnings sharing succinctly is difficult, given the multitude of parameterizations explored during this issue’s heyday. Such proposals clearly could improve the program's equity for two-earner couples, though there were significant concerns about how survivors would fare. Plans that included specific provisions to shield survivors from cuts helped to address this problem, but they significantly raised total costs.

Among the clear distributional trends from such plans were large gains for divorced women (often most especially to those who had divorced after a marriage that lasted less than 10 years), which corresponded with large losses for divorced men. ${ }^{10}$ Given that divorced men tend to lose under earnings sharing, one might question whether such plans could create marriage disincentives for men. The way that earnings sharing options interact with the benefit formula (if it is unadjusted) also turn out to be quite relevant, and could lead to some unusual (typically progressive) patterns. ${ }^{11}$

In the 1990s, issues surrounding Social Security adult auxiliary benefits received less attention relative to the earnings sharing days, with the noteworthy exception of proposals to trade lower spouse benefits for higher survivor benefits for couples with relatively similar earnings (for example, Hurd and Wise 1991, Burkhauser and Smeeding 1994, Sandell and Iams 1997, Iams and Sandell 1998). Such plans would typically reduce spouse benefits to a third of PIA in exchange for a survivor benefit that would equal some multiple (usually 67 or 75 percent) of the couple's benefit when both were alive. Research found that this kind of plan can reduce

\footnotetext{
${ }^{10}$ Married couples with very similar earnings histories should see little change if they were married to one another for most of their working years. Never-married people would not see benefit changes under earnings sharing (unless universal changes to benefits were made to compensate for associated cost savings).

${ }^{11}$ For example, under many parameterizations intact couples with one spouse with lifetime earnings below the first bend point and the other with earnings above it would gain relative to current law while both spouses were alive. The same is true where one spouse's earnings fall above the second bend point and the other's fall above it. Conversely, intact couples with workers in the same band of the PIA formula would lose if the lower AIME person dies sooner than the higher AIME person.
} 
poverty among aged women, improve equity for spouses with more similar earnings, and improve work incentives. Such plans do nothing to help some other vulnerable groups (like never married mothers) and, in some cases, could increase aggregate transfers to married people (making the proposals problematic for never married people). Careful design of caps on the survivor benefits can help to reduce such transfers to ever-married people who do not have significant need.

A few more recent studies (Favreault and Sammartino 2002, Favreault, Sammartino, and Steuerle 2002, Herd 2004, 2006) have renewed attention to issues related to adult auxiliary benefits within Social Security. They have tended to focus on incremental changes, including caregiver credits, minimum benefits, and also other benefit changes (e.g., expansion of eligibility or benefit for divorced spouses).

Proposals for caregiver credits and related provisions (e.g., increasing the number of "dropout years" for people who care for children) have often been popular because they establish a clearer link between auxiliary benefits and childrearing (as opposed to legal marital status). They provide a more appealing rationale than current law if one believes that a retirement system goal is to compensate for costs (childrearing typically adds to costs, while marriage or combining households typically reduces them). Analyses typically find that caregiver credits do better than current law spouse benefits at reducing poverty or otherwise redistributing to those in lower income groups, especially by race and class (Herd 2006, Holden 1982, Favreault, Sammartino, and Steuerle 2002). In some designs, such credits could reduce work incentives, contrary to objectives for the system. Like spouse benefits, they raise issues of who ought to pay for added protection (Fierst 1982). The literature clearly shows that caregiver credits are more progressive than increased dropout years for care (Herd 2006, Iams and Sandell 1994). Caregiver credits do raise a number of design issues (for example, how large should credits be, which parent gets the credit, whether credits need to be applied when children are young, how to adjust for additional children, etc.).

Minimum benefits clearly have the capacity to significantly reduce poverty relative to current law structures like the spouse benefit (Herd 2005, Favreault and Sammartino 2002, Favreault, Sammartino, and Steuerle 2002). Like caregiver credits, they raise a number of design issues (for example, Favreault, Mermin, and Steuerle 2006). In some designs, minimum benefits could reduce work incentives at certain earnings levels, leading to flattening benefit distributions. 
This raises concerns among many program advocates, who see the clear earnings relationship for OASDI worker benefits as a source of political support and worry that "too much" redistribution through a minimum or other means (e.g., adding another bend point) could undermine this.

Expansions of divorced spouse benefits (for example, reducing the marriage duration requirement) help relatively small fractions of those at risk, but their effects tend to be large for those who are affected (Favreault and Sammartino 2002; Weaver 1997 explores related issues). These approaches also tend not to have good work incentives, and in some cases could encourage divorce.

Summary: The literature has shown that changes to adult auxiliary benefits can be most effective if they contain packages of parameter changes. Virtually all changes in isolation fail to right certain issues, and often the improvements that changes make in one area (say, adequacy) lead to reductions in another (say, efficiency). Table 1 suggests this quite clearly. If we look across any row, none of the proposals simultaneously improves program performance along all the criteria, and many improve on one criterion only at the expense of another.

Our contribution to the literature is thus fourfold. First, we do focus on packages of parameter changes. We combine Social Security equity and adequacy adjustments in the hope that we can improve the system's performance along both types of criteria simultaneously. Second, we update several of these prior studies to take into account more recent patterns in work and family life. This is especially important in the case of earnings sharing, where the most recent studies are about twenty years old. Third, many of the previous studies tend to describe a policy environment that is “add-on” in terms of Social Security expenditures relative to current law scheduled or do not allow expenditure-neutral comparisons across different types of proposals, especially considered in combination. We take a more realistic path of assuming approximate expenditure neutrality (relative to scheduled benefits), thus paying for every change that we make. Finally, we also examine horizontal equity issues, often neglected in more recent literature that has focused on adequacy and redistribution.

\section{Parameterizations of the options/alternatives}

We have simulated three plausible combinations of parameters within option packages. In all cases, we eliminate, reduce, and/or cap spousal and survivor benefits to offset the costs of 
the provisions that are geared at improving the adequacy and equity of auxiliary benefits. Table 2 summarizes the details of the packages we explore.

Option 1. Earnings Sharing: Our first option is a generic earnings-sharing proposal, much like those advanced a few decades ago. Under it, persons becoming entitled to OASDI in 2007 (those born in 1947 or later) begin sharing earnings retrospectively starting in $1961 .^{12}$ Earnings sharing occurs for the full duration of the marriage, but no longer. ${ }^{13}$ In concert with this change, we remove all spouse benefits. We simulate three sub-options of earnings sharing that handle adjustments to survivor benefits differently. In the first (1a), we award survivor benefits on the basis of the maximum shared earnings vector among a worker's, his/her spouse's, and all former spouses'. This would be equivalent to removal of the survivor benefit for those who were married to one another for their highest 35 years of earnings, but could have variable (and somewhat unusual, sometimes undesirable) effects for those with qualifying marriages of lesser duration. We chose this specification despite these effects because of its similarity to current law, which now chooses the highest of ones and one's spouses' unshared vectors. In the second sub-option (1b), we remove the survivor benefit altogether. This is more consistent with earnings sharing principles as traditionally constructed. In the third version (1c), we also eliminate all survivor benefits, but further require those who are married at the time of first benefit entitlement to accept benefit reductions to finance a survivor benefit in case they predecease their spouse. Such adjustments were discussed in the earlier earnings sharing debates (e.g., Burkhauser 1982). The financing of the benefit offset to pay for the survivor is designed to be roughly actuarially fair on a cohort basis, and uses unisex pricing. ${ }^{14}$ We impose this survivor benefit mandate for both higher and lower earners in a couple.

Because in all three sub-options these changes to Social Security lead to cost reductions relative to current law scheduled (i.e., the full or partial elimination of spouse and survivor

\footnotetext{
${ }^{12}$ We re-compute covered quarters on the basis of this shared vector.

13 One might argue for extending the sharing period when children are involved, applying different sharing rules for couples with and without children, or making additional corrections for other types of career sacrifices (e.g., putting a spouse through a costly schooling program). For example, in marriages with children, there could be presumptive entitlement to share earnings for the custodial parent from birth through the age when a child is no longer dependent (though this becomes complicated if either spouse remarries before the child reached the designated age for nondependence). Similarly, if it is earlier, one could consider a child's birth as a better indicator of the period a couple should share over than a marriage's start date, though this certainly stretches current OASDI law regarding spouses. ${ }^{14}$ A mandate of this sort complicates assessment of cost-neutrality, especially at a point in time. Because this proposal significantly alters time paths of benefit costs (by requiring couples to take lower benefits earlier in life to
} 
benefits more than offsets benefit increases certain families will receive because of changes to fractions of total earnings in each bracket of the PIA formula), we make scalar adjustments to worker benefits (namely, through adjustments to the formula factors). In the first instance, we increase benefits by about 2.7 percent. In the second and third, we increase benefits more, about 4.5 percent. (One could of course make these increases more progressive, rather than proportional to the newly defined individual benefit, for example by increasing the first two formula factors proportionately more than the third.)

Option 2. Reduce Spousal and add a Minimum Benefit. Our second option contains far simpler changes relative to current law. Effective for those becoming entitled in 2007, we reduce spousal benefits from 50 percent of PIA under current law to 12.5 percent. To compensate for this reduction, we implement a minimum benefit that anyone can qualify for, regardless of marital status or marital history. The minimum benefit we use is fairly standard from the literature. Under it, a worker qualifies for a benefit of 60 percent of poverty with 20 years of work, increasing by two percent of poverty per year of work until reaching a maximum poverty-level benefit with 40 years of Social Security-covered work. The minimum benefit is wage-indexed from its inception (again, 2007). This implies (assuming that wage growth outstrips price growth, as it has historically) that the minimum's value will increase faster than poverty, so that in the subsequent years workers would receive greater than 100 percent of poverty under the minimum with 40 years of covered work.

Option 3. Reduce Spousal and add Caregiver Credits. Our final option grants an earnings credit of up to 50 percent of the average wage to women with children under the age of six when determining Social Security benefit levels. ${ }^{15}$ Effective for those first entitled in 2007, one can receive the credit for up to five years (or seven years total if one has more than one child), and it is applied retrospectively for years after $1960 .{ }^{16}$ Those who already earned more than the credit amount do not benefit from it. To offset this credit, we eliminate spousal benefits.

\footnotetext{
finance survivor benefits later), we allow it to deviate further from the current law scheduled figure for 2050. In future work, we hope to use longer-term cost equivalence as our benchmark, reducing this concern.

${ }^{15}$ The current version of this simulation applies the credits to mothers, but not fathers. We use this parameterization, even though it is not realistic because of Social Security law's full sex-neutrality in recent decades, because of data limitation that make it more difficult to track fathers' relationships to their children than mothers'. This assumption would be less problematic for current beneficiaries than it is for future ones. We thus suggest conservative interpretation of the results, and hope to expand on them in future work.

${ }^{16}$ Credits are applied sequentially from the birth of the first child (rather than in a way that maximizes the credit). We re-compute covered quarters after adding in the credit to the earnings history.
} 


\section{Methods}

To explore these issues, we use DYNASIM3, the Urban Institute's dynamic microsimulation model. DYNASIM3 has a starting population based on the 1990 to 1993 panels of the Survey of Income and Program Participation. Year by year, the model makes forecasts of life events (births, deaths, disability, marriage, divorce), work behavior, Social Security receipt, and other retirement income sources as far as 2050 (see Favreault and Smith 2004). The model makes different forecasts based on individual characteristics (like education and race) and life histories (as observed to date). For example, many women change their work behavior when they have marry, have children, or divorce. We calibrate many predictions (for example, on fertility levels and wage growth) to the assumptions of the Social Security Trustees (OASDI Board of Trustees 2005).

We code the three alternative OASDI family benefit systems into the model, and forecast their effects through 2050. In our lifetime analyses, we forecast outcomes further (to 2100) but using a more limited set of outcomes and differentials. We assume that individuals behave the same way under the options (earnings sharing, others) as they would under current law scheduled. So work and marriage behavior do not change because of the options' introduction. We also assume that administrative costs are similar across options. ${ }^{17}$

Our outcome measures for the simulations include average annual worker and auxiliary benefits at points in time (for example, 2049) and average/median lifetime Social Security benefits for select cohorts. We tabulate these outcomes along a wide variety of characteristics of interest, including age, childrearing history (i.e., the number of years one spent raising children), education, gender, marital status/history, lifetime earnings, and work history. Such tabulations help us to determine the extent to which a given option makes Social Security more (or less) tied to marital status, childbearing, earnings, relative earnings of spouses, and work history. To capture changes in horizontal equity, we examine the extent to which individuals and couples paying the same total amount in payroll taxes (but with different fractions of lifetime earnings

\footnotetext{
${ }^{17}$ While this assumption is fairly reasonable for the more incremental options, it is less plausible for the earnings sharing options, given that they would require significant changes to existing procedures and data linkages.
} 
earned by each spouse) receive similar benefits. To specifically measure benefit adequacy, we compute the reduction in the share of the population in poverty (and reduction in the gap between Social Security benefits and poverty). In all cases, we compare Social Security outcomes under each option to current law scheduled along these dimensions.

\section{Results}

Winners and Losers: We begin our discussion with some summary results on winners and losers from the options (Table 3). This table shows the fractions of beneficiaries with benefit changes of varying magnitudes (expressed as a percent of current law benefit) by sex and in different marital status groups in the year 2049 across the three options (and including the three earnings sharing sub-options).

For earnings sharing, the sorts of basic patterns we would expect to find given our selected parameterizations (and the previous literature) are apparent. These include transfers to divorced women, about 16 percent of whom experienced benefit increases of over 20 percent relative to current law in the first parameterization. Divorced men are more likely to lose benefits, with 18 percent losing greater than 10 percent. (Substantial fractions of the former husbands of the divorced women who gain are likely fall into the married category, as are some formerly divorced women, given remarriage, which is somewhat more prevalent among men than among women.) Never married people receive small benefit increases (because of the benefit adjustment that compensates for the elimination of spouse and survivor benefits) under this first earnings sharing option. Married people experience a mix of gains and losses. The largest gains are concentrated among lower-earnings spouses whose higher-earnings spouses have not yet claimed benefits (gains that will be reduced when the second earner claims his/her benefit that has now been reduced because of sharing) and among those where spouses have lifetime earnings that occupied different brackets of the PIA formula. ${ }^{18}$ Losses are concentrated among those families that had been receiving sizable spouse benefits (whether spouse only or dual entitlement top ups). The gains that the divorced, some married, and never married receive

\footnotetext{
18 One odd thing that happens under earnings sharing is that quite a few spouse beneficiaries can actually "win" (i.e., receive higher benefits), both at a point in time and over a lifetime. Most commonly, this occurs when more of the couple earnings fall below the lower two bend points and thus are subject to higher replacement rate. There are also instances where a spouse may have had 8 or 9 years of covered earnings that were not being counted under current law. With the earnings sharing (which re-computes covered quarters based on the shared husband and wife earnings vector), these earnings now count toward Social Security. Other times, a spouse is now receiving benefits on a more lucrative total vector (if, say, the current spouse was not the spouse with the highest lifetime earnings).
} 
come largely at the expense of widowed men and women. About three-quarters receive a loss of some size, and about a fifth of widowers and widows (20 and 15 percent, respectively) experience benefit losses of twenty percent or higher. When the earnings sharing option includes no survivor benefit (rather than one based on the highest shared vector) and benefits are increased in a scalar way accordingly, we see more significant fractions with large losses among both the married and, especially, the widowed. Fractions of widow(er)s with losses of greater than 20 percent increase to 36 percent of men and 38 percent of women under this option. Mandating survivor annuitization, in contrast, leads to more substantial losses among married people (notice the concentration of losses in the 5 to 20 percent range for this group), but leads to gains among many widow(er)s. We can interpret these shifts to some degree as redistribution from oneself earlier in life (when work capacity is greater and resources are less likely to be scarce) to oneself later in life.

The option that reduces spouse benefits and adds a minimum benefit has a very different pattern of gains and losses than the earnings sharing options. Most people fall into the no change category, with widows and widowers the groups least likely to experience a change. About 15 percent of never married people see increased benefits because of the new minimum benefit. Losers, of course, are concentrated among the married people who experienced the spouse benefit reduction. About a fifth of married men and a quarter of married women lose, compared to about 15 percent who gain. Divorced people have mixed experiences. A small fraction (presumably former divorced spousal beneficiaries) receives very large reductions, while a somewhat larger fraction experiences large increases (presumably because of the new minimum).

Caregiver credits with a spousal benefit reduction have a broad reach. More people have changes to their benefits than under the minimum benefit option, but the sizes of benefit changes tend to be fairly modest. Gains and losses are asymmetrical, with losses (presumably primarily from the spouse only beneficiaries) much larger than the gains, which are concentrated in the range of less than five percent of original benefits.

\section{Lifetime tax-benefit ratios: We compare lifetime OASDI tax-benefit ratios across} individuals by the relative earnings of spouses (within lifetime tax payment groups) to highlight the options' performance on equity criteria. ${ }^{19}$ Such measures allow us to expand on the winners

\footnotetext{
${ }^{19}$ In constructing this measure, we sum contributions and benefits from age 16 to death, using a discount rate of two percent. We evaluate outcomes as of age 65, and consider only persons who survive to age 30. We include people
} 
and losers at a point in time, and accumulate experience throughout a career. Table 4 presents these data on individuals born between 1960 and 1980 (who effectively experience the new systems when they are essentially fully phased in). ${ }^{20}$ A ratio of greater than one indicates that a person receives lifetime benefits that exceed his/her payroll tax contributions, accumulated at a two percent real rate of return. A ratio of less than one indicates that contributions exceeded benefits (so accumulated). The declining ratios across increasing lifetime tax groups in the current law column illustrate the system’s progressivity.

We see that the three earnings sharing options clearly reduce the high ratios of those couples with disparate relative earnings (Table 4). Ratios for single-earner families and those couples with highly or very highly skewed earnings (couples in which one spouse earned more than 80 percent of the total) decline or remain flat in all three lifetime tax groups that we examine. The spouse minimum benefit option similarly improves the balance of ratios across earnings fraction groups (within tax groups), though in some cases somewhat less so than earnings sharing. Caregiver credits with spousal reductions do similarly to the minimum benefit. It is striking how muted the patterns are on this outcome, with a lot of noise around the general trends. This appears to be due to variation within the earnings/tax category, plus the fact that so many people have relatively complex work and marriage trajectories (with a lot of people shifting among family earnings types, significant amounts of remarriage, and/or spouses whose ages are relatively far apart, meaning that one collects on the shared record before the other).

Poverty: To weigh the proposals' adequacy effects, we turn to our results on poverty reduction in 2049 (Table 5). ${ }^{21}$ The earnings sharing option that allows one to collect survivor benefits based on the highest shared earnings vector and increased benefits by 2.7 percent reduced poverty relative to current law scheduled for the population at large (with a poverty rate of 4.96 percent, compared to 5.17 under current law). The earnings sharing option with mandated survivor protection does even better, reducing poverty to a rate of 4.79 percent. The minimum benefit reducing spouse benefits has the greatest effect on poverty, reducing it to 4.59

who survive to age 30 but die prior to collecting Social Security benefits in the population. (They have benefit-tocontribution ratios of zero.)

${ }^{20}$ We calculate these ratios on the individual level, and then average them. This implies that our measure is the average ratio for a member of a group, but not the average for the group as a whole.

${ }^{21}$ The limitations of poverty as an adequacy measure, especially in such a long-term context, are well-known. Additional adequacy results, for example estimates of near poverty (e.g., income of less than 125 percent of the poverty level), are available upon request. 
percent. The caregiver credit has poverty effects that fall between the earnings sharing with modified survivor and the minimum benefit, 4.91 percent. The earnings sharing proposal with elimination of all survivor benefit, in contrast, increases poverty, to 5.48 percent of the population. While these differences in poverty may appear modest (a range of 0.9 percentage points from highest to lowest), a shift of just 0.1 percentage points reflects almost 93,500 people in this 2049 population. So potentially hundreds of thousands of people could be removed from poverty (relative to current law scheduled) across the options.

The poverty change effects are differentiated by marital status across all of the options, largely mirroring the patterns of gains and losses we showed earlier. Earnings sharing options reduce poverty among the divorced (and even some of the married) at the expense of the widowed. Earnings sharing with mandated survivor protection, however, can mitigate the effect on the widowed, though at the expense of the married. The minimum benefit package reduces poverty among all the marital status groups, but is less successful for the divorced than is earnings sharing. The caregiver helps women in virtually all of the marital status groups, at the expense of men in single-earner families in this particular specification.

\section{Caveats}

Our projections depend on accurate modeling of the relative earnings of men and women as well their choices about marriage, childbearing, and divorce several decades from now. Given challenges in forecasting such tends over even short periods, we suggest conservative interpretation of our results.

Because we balance costs for the various options at a point in time (2050), the long-term equivalence of these proposals is not assured (tables with the time paths of costs are available on request). We hope to impose a more rigorous standard of longer-term balance in future work. Further, we assume no behavioral responses or changes to transaction costs in these analyses. If any of the options were to improve work incentives, they may reduce Social Security financing problems and increase individual and family-level benefits. If they were to promote or discourage marriage and/or divorce, results could differ significantly. Caregiver credits and, especially, earnings sharing would likely increase administrative costs. Finally, the proposals we simulate are stylized, often without any phase-ins. Congress usually implements changes to Social Security benefit accruals with significant notice and/or incorporates significant phase-in periods or provisions in legislation. 


\section{Conclusions and policy implications}

All three of our packages - earnings sharing, replacement of most of the spouse benefit with a minimum, and full spouse replacement with caregiver credits — reduced poverty modestly and made lifetime benefits more similar for couples paying the same amount in taxes relative to current law scheduled, though the earnings sharing proposal only reduced poverty when we made significant adjustments to the treatment of surviving spouses through a selffinanced survivor benefit. The packages do reveal important tradeoffs among different beneficiary groups. The (crudely) cost-neutral environment in which we work underscores how improving adequacy for some groups has significant repercussions for others in an underfunded system.

Of course, the options that we have simulated are relatively stylized ones, meant primarily to illustrate some possible ways the Social Security system might evolve to meet the needs of today's increasingly diverse American families. The performance of all could be improved along our evaluation criteria through additional parameter adjustments. Our hope is that we have encouraged renewed attention to examining these issues using methods that enable one to identify distributional effects and outcome measures that are based on objectives that improve the system's fairness and capacity to help those in need in retirement and disability. 


\section{References:}

Burkhauser, Richard V. 1982. “Earnings Sharing: Incremental and Fundamental Reform.” In Burkhauser, R.V. and K. C. Holden, eds. 1982. A Challenge to Social Security: The Changing Roles of Women and Men in American Society. New York: Academic Press.

Burkhauser, Richard V. and Karen C. Holden, eds. 1982. A Challenge to Social Security: The Changing Roles of Women and Men in American Society. New York: Academic Press.

Burkhauser, Richard V., Karen C. Holden, and D. Myers. 1986. "Widowhood and Poverty: The Role of Survey Procedures in Artificially Creating Poverty.” Demography 23(4): 621631.

Burkhauser, Richard V. and Timothy M. Smeeding. 1994. Social Security Reform: A Budget Neutral Approach to Older Women's Disproportionate Risk of Poverty. Syracuse, NY: Syracuse University, Center for Policy Research, Maxwell School.

Butrica, Barbara A. and Howard M. Iams. 2000. "Divorced Women at Retirement: Projections of Economic Well-Being in the Near Future.” Social Security Bulletin 63(3): 3-12.

Congressional Budget Office (CBO). 1986. Earnings Sharing Options for the Social Security System. January.

Brien, Mike, Stacy Dickert-Conlin, and David Weaver. 2004. "Widows Waiting to Wed? (Re)Marriage and Economic Incentives in Social Security Widow Benefits.” Journal of Human Resources 39(3): 585-623.

DeNavas-Walt, Carmen, Bernadette D. Proctor, and Cheryl Hill Lee. 2006. Income, Poverty, and Health Insurance Coverage in the United States: 2005. U.S. Census Bureau, Current Population Reports, P60-231. Washington, DC: U.S. Government Printing Office. www.census.gov/prod/2006pubs/p60-231.pdf (accessed September 2006).

Dye, Jane Lawler. 2005. “Fertility of American Women: June 2004.” Current Population Reports P20-555. http://www.census.gov/prod/2005pubs/p20-555.pdf (accessed June 2006).

Favreault, Melissa M., Gordon B. T. Mermin, and C. Eugene Steuerle. 2006. "Minimum Benefits and Social Security." Washington, DC: AARP. [Project Report for AARP Public Policy Institute, Number 2006-17.] http://www.aarp.org/research/socialsecurity/benefits/2006_17_socsec.html (accessed December 2006).

Favreault, Melissa M. and Frank J. Sammartino. 2002. “Impact of Social Security Reform on Low-Income and Older Women.” Washington, DC: AARP. [Project Report for AARP Public Policy Institute, Number 2002-11.]

Favreault, Melissa M., Frank J. Sammartino, and C. Eugene Steuerle, eds. 2002. Social Security and the Family: Addressing Unmet Needs in an Underfunded System. Washington, DC: Urban Institute Press.

Favreault, Melissa M. and Karen E. Smith. 2004. "A Primer on the Dynamic Simulation of Income Model (DYNASIM3).” Discussion Paper, Retirement Project, The Urban Institute. http://www.urban.org/UploadedPDF/410961_Dynasim3Primer.pdf (accessed December 2004).

Feldstein, Martin and Andrew Samwick. 1992. "Social Security and Marginal Tax Rates.” National Tax Journal 45(1): 1-22.

Ferber, Marianne A. 1993. “Women’s Employment and the Social Security System.” Social Security Bulletin 56(3): 33-55. 
Fierst, Edith U. 1982. “Discussion.” In R.V. Burkhauser and K. C. Holden, eds. A Challenge to Social Security: The Changing Roles of Women and Men in American Society. New York: Academic Press.

Harrington Meyer, Madonna. 1996. "Making Claims as Workers or Wives: The Distribution of Social Security Benefits.” American Sociological Review 61(3): 449-465.

Harrington Meyer, Madonna, Douglas A. Wolf, and Christine L. Himes. 2004. “Linking Benefits to Marital Status: Race and Diminishing Access to Social Security Spouse and Widow Benefits in the U.S.” Center for Retirement Research at Boston College. WP \#2004-05. http://www.bc.edu/centers/crr/wp_2004-05.shtml (accessed July 2006).

Herd, Pamela. 2006. "Crediting Care or Marriage? Reforming Social Security family benefits." Journals of Gerontology, Series B: Psychological and Social Sciences, 61: S24-34.

Herd, Pamela. 2005. "Ensuring a Minimum: Social Security Reform and Women.” The Gerontologist 45(1): 12-25.

Herd, Pamela. 2004. "Reforming Social Security Family Benefits: Balancing Equity and Adequacy.” Pp. 114-126 in K. Buto, M. Priddy Patterson, W. E. Spriggs, M. Rockeymoore, eds. Strengthening Community: Social Security in a Diverse America. Washington, DC: Brookings Institution Press.

Holden, Karen C. 1979. "The Inequitable Distribution of OASI Benefits Among Homemakers." Gerontologist 19(3): 250-256.

Holden, Karen C. 1982. "Supplemental OASI Benefits to Homemakers Through Current Spouse Benefits, a Homemaker Credit, and Child-Care Drop-Out Years.” In R. V. Burkhauser and K. C. Holden, eds. 1982. A Challenge to Social Security: The Changing Roles of Women and Men in American Society. New York: Academic Press.

Hurd, Michael D. and David A. Wise. 1991. "Changing Social Security Survivorship Benefits and the Poverty of Widows.” Working Paper no. 3833. Cambridge, MA: National Bureau of Economic Research. (Also in M.D. Hurd and N. Yashiro, eds. 1997. The Economic Effects of Aging in the United States and Japan. Chicago: University of Chicago Press.)

Iams, Howard M. and Steven H. Sandell. 1998. “Cost-Neutral Policies to Increase Social Security Benefits for Widows: A Simulation for 1992.” Social Security Bulletin 61(1): 34-43.

Iams, Howard M. and Steven H. Sandell. 1994. "Changing Social Security Benefits to Reflect Child-Care Years: A Policy Proposal Whose Time Has Passed?” Social Security Bulletin 57(4): 10-23.

Johnson, Richard W. and Melissa M. Favreault. 2004. "Economic Status in Later Life Among Women Who Raised Children Outside of Marriage.” Journal of Gerontology: Social Sciences 59B(6): S315-S323.

OASDI Board of Trustees. 2005. 2005 Annual Report of the Board of Trustees of the Federal Old-Age and Survivors Insurance and Disability Insurance Trust Funds. Washington, DC: Author.

Ozawa, Martha N. and Hak-Ju Kim. 2001. “Money’s Worth in Social Security Benefits: BlackWhite Differences.” Social Work Research 25(1): 5-14.

Reno, Virginia P., Michael J. Graetz, Kenneth S. Apfel, Joni Lavery, and Catherine Hill, eds. 2005. Uncharted Waters: Paying Benefits from Individual Accounts in Federal Retirement Policy. Study Panel Final Report. Washington, DC: National Academy of Social Insurance. 
Roberts, Sam (with Ariel Sabar, Brenda Goodman, and Maureen Balleza). 2007. “51\% of Women are Now Living without a Spouse.” The New York Times January 16, p. A1.

Ross, Jane L. and Melinda M. Upp. 1993. "Treatment of Women in the U.S. Social Security System, 1970-88.” Social Security Bulletin 56(3): 56-67.

Sandell, Steven H. and Howard M. Iams. 1997. "Reducing Women’s Poverty by Shifting Social Security Benefits from Retired Couples to Widows.” Journal of Policy Analysis and Management 16(2): 279-297.

Smeeding, Timothy M., Carroll L. Estes, and Lou Glasse. 1999. "Social Security and Older Women: Improving the System.” Income Security Policy Series Paper Number 22. Syracuse, NY: Maxwell School.

Social Security Administration. 2006. Income of the Population 55 or Older, 2004. Office of Policy. Washington, DC: Author.

Social Security Administration. 2007. Annual Statistical Supplement, 2006 to the Social Security Bulletin. Washington, DC: Author. www.ssa.gov/policy/docs/statcomps/supplement/2006/ (accessed January 2007).

Steuerle, C. Eugene. 1999. Statement before the Committee on Aging, United States Senate, "The Treatment of the Family and Divorce in the Social Security Program,” February 22.

U.S. Department of Health and Human Services. 1985. Report on Earnings Sharing Implementation Study, January.

U.S. Department of Health, Education, and Welfare. 1979. Social Security and the Changing Roles of Men and Women. Washington, DC: Author.

Weaver, David A. 1997. "The Economic Well-Being of Social Security Beneficiaries, with and Emphasis on Divorces Beneficiaries.” Social Security Bulletin 60(4): 3-17.

Zedlewski, Sheila Rafferty. 1984. "The Distributional Consequences of an Earnings Sharing Proposal.” Project Report No. 3344. Washington, DC: The Urban Institute. 
Table 1. Performance of Selected Proposals to Improve Social Security's Family Benefits Along Various Criteria: Findings from the Literature

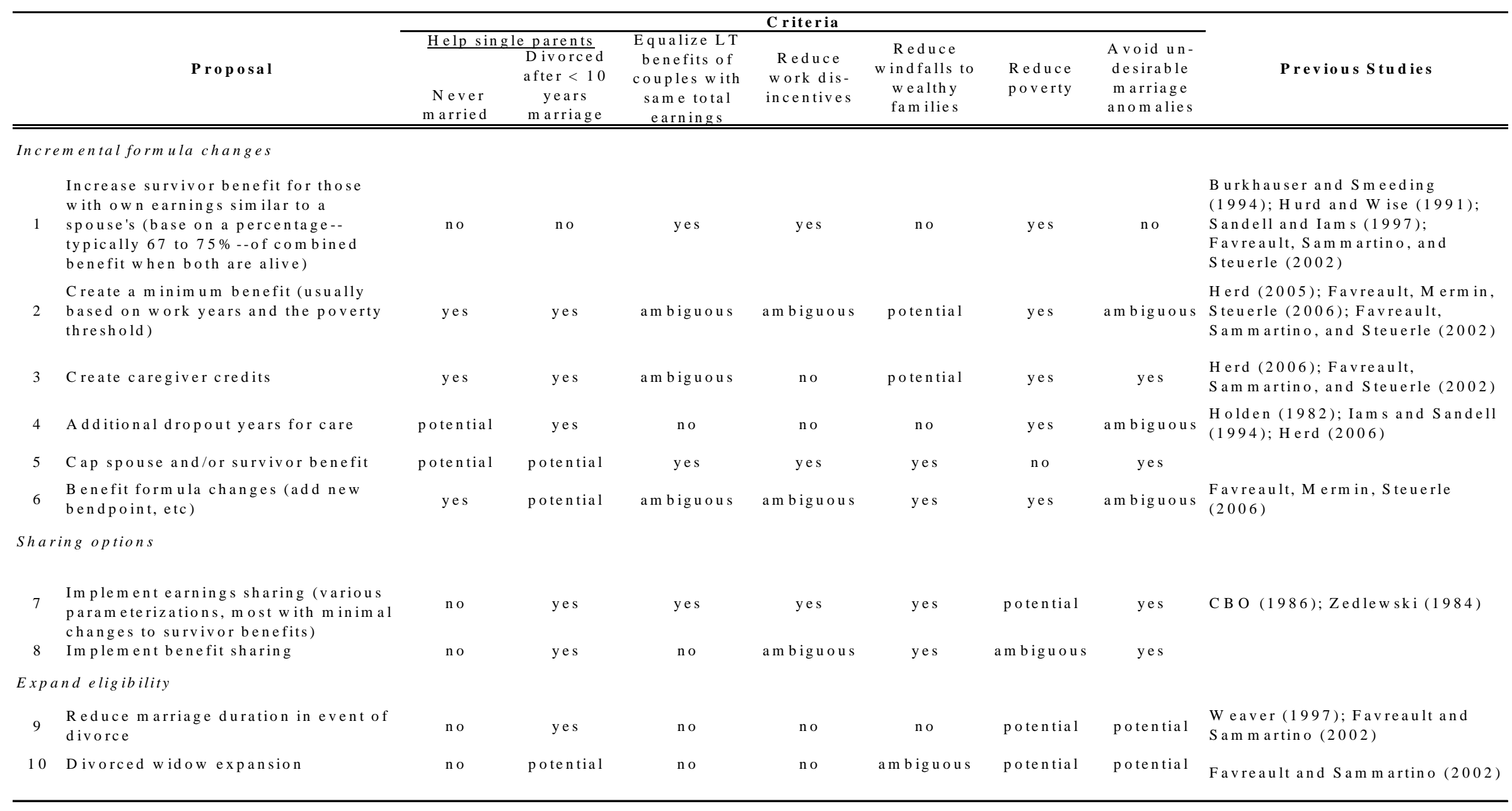

Notes: Evaluations of the performance on the criteria are typically made relative to current law (under the assumption that funds saved, if any, are redistributed among workers). To the extent that studies have used particular cost-offsets, they have typically been reduction or elimination of the spousal benefits. 
Table 2. Details of the Social Security Packages Simulated

\begin{tabular}{|c|c|c|c|c|}
\hline & Proposal & Details & Cost Offset & $\begin{array}{l}\text { Implem entation Issues (e.g., phase-ins, } \\
\text { D I) }\end{array}$ \\
\hline 1 a & $\begin{array}{l}\text { Earnings sharing with } \\
\text { modified survivors' } \\
\text { benefits, global benefit } \\
\text { increase of } 2.71 \text { percent }\end{array}$ & $\begin{array}{l}\text { Spouses share all earnings (capped at the taxable } \\
\text { maximum prior to sharing) over the duration of } \\
\text { marriage. We apply sharing retrospectively to } \\
\text { earnings beginning in } 1961 \text {. We recompute } \\
\text { quarters of coverage based on the shared earnings } \\
\text { vector. }\end{array}$ & $\begin{array}{l}\text { Eliminate spousal } \\
\text { benefit. Reduce } \\
\text { survivor benefits, } \\
\text { allowing survivor to } \\
\text { receive on the } \\
\text { maximum shared } \\
\text { earnings vector. }\end{array}$ & $\begin{array}{l}\text { We implement sharing at time of beneficiary } \\
\text { entitlement to all ever married persons. We do } \\
\text { not wait until both spouses are retired/disabled } \\
\text { or divorce occurs to split. Partial years of } \\
\text { marriage are treated as if spouses were married } \\
\text { all year. Immigrants share their time abroad } \\
\text { (zero years) with a spouse. We implement } \\
\text { benefit hikes through a scalar increase to bend } \\
\text { percentages. }\end{array}$ \\
\hline $1 \mathrm{~b}$ & $\begin{array}{l}\text { Earnings sharing with no } \\
\text { survivors' benefits, global } \\
\text { benefit increase of } 4.5 \\
\text { percent }\end{array}$ & Same as 1 a, except no survivor benefit whatsoever & $\begin{array}{l}\text { Benefit increase from } \\
\text { survivor/spouse } \\
\text { removal is higher } \\
\text { than in } 1 \text { a. }\end{array}$ & $\begin{array}{l}\text { As in } 1 \text { a, except for survivor provisions as } \\
\text { indicated. }\end{array}$ \\
\hline $1 \mathrm{c}$ & $\begin{array}{l}\text { Earnings sharing with } \\
\text { self-financing survivors' } \\
\text { benefits, global benefit } \\
\text { increase of } 4.5 \text { percent }\end{array}$ & $\begin{array}{l}\text { Same as } 1 \text { b, except require people married at the } \\
\text { time of entitlement to "purchase" survivor } \\
\text { insurance ( } 2 / 3 \text { of own benefit) through a benefit } \\
\text { reduction. }\end{array}$ & As in $1 \mathrm{~b}$. & $\begin{array}{l}\text { As in } 1 \text { a, plus annuity priced on unisex basis } \\
\text { using individual-and spouse-specific cohort } \\
\text { rates for self and spouse. Interest rate for } \\
\text { annuity is } 4.6 \text { percent real. When spouses are } \\
\text { different ages and/ortake up in different years, } \\
\text { we nonetheless mandate purchase at time of first } \\
\text { collection. The same is true in cases of } \\
\text { disability. }\end{array}$ \\
\hline 2 & $\begin{array}{l}\text { M inimum benefit to } \\
\text { phase out spouse benefit }\end{array}$ & $\begin{array}{l}\text { M inimum benefit provides } 60 \text { percent of poverty } \\
\text { at } 20 \text { years of work (defined based on } 4 \text { covered } \\
\text { quarters), increasing by two percent per year } \\
\text { through each additional work year up to } 40 \text {; is } \\
\text { wage-indexed starting in } 2008 \text {. }\end{array}$ & $\begin{array}{l}\text { Reduce spousal } \\
\text { benefit to } 12.5 \\
\text { percent of PIA. }\end{array}$ & $\begin{array}{l}\text { Work years requirements for the minimum } \\
\text { benefit are pro-rated for those on D I. Minimum } \\
\text { is attached to PIA calculations, so actuarial } \\
\text { reductions apply. }\end{array}$ \\
\hline 3 & $\begin{array}{l}\text { Caregiver credits to } \\
\text { phase out spouse benefit }\end{array}$ & $\begin{array}{l}\text { Up to } 5 \text { years per child, with a maximum of } 7 \\
\text { years with more than one child. Credit equals up } \\
\text { to half the average wage (less for parents with non- } \\
\text { zero earnings, who receive a top up to that level). }\end{array}$ & $\begin{array}{l}\text { Reduce spouse } \\
\text { benefit to zero. }\end{array}$ & $\begin{array}{l}\text { Applied to the first years after child's birth when } \\
\text { earnings are below credit (not years with } \\
\text { maximum credit). Years required to be when the } \\
\text { child is young. Limit one percouple (applied } \\
\text { only to wives, hope to expand in later work). }\end{array}$ \\
\hline
\end{tabular}

Notes: In all cases, the implementation takes effect in 2007 , and only for those first entitled to OASDI that year or later. (Older cohorts are grandfathered into the old system, and may not be eligible to receive enhancements, like a minimum benefit or global benefit hike.) 
Table 3. Winners and Losers (Relative to Current Law Scheduled) Among Current Law Beneficiaries Under the Options in 2049, By Sex and Marital Status in that Year

\begin{tabular}{|c|c|c|c|c|c|c|c|c|c|c|}
\hline & \multicolumn{2}{|c|}{$\begin{array}{c}\text { Package 1a: } \\
\text { Earnings sharing, } \\
\text { no spouse ben, } \\
\text { survivor }= \\
\text { maximum shared } \\
\text { vector, } 2.7 \\
\text { percent increase }\end{array}$} & \multicolumn{2}{|c|}{$\begin{array}{l}\text { Package } 1 b \text { : } \\
\text { Earnings sharing, } \\
\text { no spouse ben, no } \\
\text { survivor ben, } 4.5 \\
\text { percent increase }\end{array}$} & \multicolumn{2}{|c|}{$\begin{array}{l}\text { Package 1c: As } \\
\text { in } 1 b \text { ( Earnings } \\
\text { sharing, no } \\
\text { spouse ben, } 4.5 \\
\text { increase), only } \\
\text { self-financed } \\
\text { survivor ben }\end{array}$} & \multicolumn{2}{|c|}{$\begin{array}{l}\text { Package } 2: .125 \\
\text { spouse benefit, } \\
\text { wage-indexed } \\
\text { minimum benefit } \\
\text { (100\% poverty at } \\
40 \text { work years) }\end{array}$} & \multicolumn{2}{|c|}{$\begin{array}{c}\text { Package } 3: \text { Up } \\
\text { to } 7 \text { caregiver } \\
\text { credits (up to } 0.5 \\
\text { * avg wage), no } \\
\text { spouse benefit }\end{array}$} \\
\hline & Men & Women & Men & Women & Men & Women & Men & Women & Men & Women \\
\hline \multicolumn{11}{|l|}{ Married } \\
\hline lose $>=20 \%$ & 7.4 & 4.5 & 18.1 & 8.4 & 9.7 & 7.4 & 4.4 & 5.7 & 3.6 & 4.6 \\
\hline lose $10-19.99 \%$ & 9.4 & 6.0 & 19.9 & 7.6 & 23.7 & 24.9 & 4.0 & 5.0 & 4.3 & 5.5 \\
\hline lose $5-9.99 \%$ & 9.9 & 8.6 & 11.2 & 6.1 & 25.1 & 28.2 & 3.9 & 5.0 & 4.9 & 6.3 \\
\hline lose < $5 \%$ & 16.7 & 17.6 & 10.3 & 6.6 & 14.3 & 14.7 & 6.0 & 7.7 & 6.1 & 7.9 \\
\hline no change & 0.2 & 0.0 & 0.0 & 0.0 & 0.0 & 9.1 & 67.3 & 61.0 & 56.3 & 34.2 \\
\hline gain < 5\% & 25.0 & 28.2 & 11.1 & 11.0 & 10.3 & 9.1 & 4.9 & 5.8 & 21.6 & 31.7 \\
\hline gain 5-9.99\% & 12.1 & 13.6 & 6.0 & 6.5 & 4.2 & 3.0 & 2.8 & 3.3 & 1.7 & 4.2 \\
\hline gain $10-19.99 \%$ & 9.0 & 10.0 & 6.5 & 9.7 & 3.4 & 2.7 & 2.8 & 3.0 & 0.8 & 2.9 \\
\hline gain >=20\% & 10.2 & 11.5 & 17.0 & 44.1 & 9.5 & 10.0 & 3.9 & 3.5 & 0.6 & 2.7 \\
\hline All & 100.0 & 100.0 & 100.0 & 100.0 & 100.0 & 100.0 & 100.0 & 100.0 & 100.0 & 100.0 \\
\hline \multicolumn{11}{|l|}{ Divorced } \\
\hline lose $>=20 \%$ & 5.6 & 3.0 & 7.6 & 9.2 & 6.0 & 3.2 & 1.3 & 3.5 & 2.3 & 3.3 \\
\hline lose $10-19.99 \%$ & 12.5 & 7.2 & 11.8 & 4.7 & 10.0 & 6.0 & 1.0 & 1.5 & 1.1 & 1.8 \\
\hline lose $5-9.99 \%$ & 12.5 & 6.0 & 10.1 & 3.7 & 9.9 & 5.2 & 0.3 & 0.7 & 0.1 & 1.1 \\
\hline lose $<5 \%$ & 19.1 & 12.2 & 15.1 & 7.3 & 16.3 & 8.3 & 0.9 & 0.8 & 0.8 & 0.9 \\
\hline no change & 0.4 & 0.6 & 0.1 & 0.0 & 0.0 & 0.0 & 84.6 & 83.2 & 95.4 & 59.1 \\
\hline gain $<5 \%$ & 32.4 & 32.5 & 34.4 & 30.4 & 34.7 & 31.0 & 2.4 & 1.5 & 0.3 & 17.6 \\
\hline gain $5-9.99 \%$ & 7.5 & 12.9 & 9.8 & 16.3 & 9.9 & 16.6 & 1.8 & 1.9 & 0.0 & 8.1 \\
\hline gain $10-19.99 \%$ & 4.6 & 9.6 & 5.7 & 11.5 & 6.3 & 12.0 & 2.6 & 2.0 & 0.0 & 3.5 \\
\hline gain $>=20 \%$ & 5.4 & 16.2 & 5.6 & 16.9 & 7.0 & 17.8 & 5.2 & 4.9 & 0.0 & 4.5 \\
\hline All & 100.0 & 100.0 & 100.0 & 100.0 & 100.0 & 100.0 & 100.0 & 100.0 & 100.0 & 100.0 \\
\hline \multicolumn{11}{|l|}{ Widowed } \\
\hline lose $>=20 \%$ & 19.6 & 15.3 & 35.6 & 38.3 & 5.8 & 5.3 & 0.1 & 0.1 & 0.1 & 0.2 \\
\hline lose $10-19.99 \%$ & 29.9 & 24.2 & 28.6 & 17.4 & 9.7 & 8.0 & 0.1 & 0.1 & 0.1 & 0.1 \\
\hline lose $5-9.99 \%$ & 16.3 & 16.0 & 14.3 & 11.0 & 8.0 & 7.2 & 0.1 & 0.1 & 0.2 & 0.0 \\
\hline lose $<5 \%$ & 12.3 & 16.0 & 10.0 & 10.2 & 8.3 & 7.7 & 0.0 & 0.1 & 0.0 & 0.1 \\
\hline no change & 0.2 & 1.7 & 0.0 & 0.0 & 0.0 & 0.0 & 89.9 & 92.9 & 94.3 & 85.4 \\
\hline gain $<5 \%$ & 11.7 & 15.2 & 7.2 & 12.0 & 8.8 & 13.5 & 5.9 & 3.0 & 5.0 & 9.9 \\
\hline gain $5-9.99 \%$ & 4.9 & 5.7 & 2.0 & 5.5 & 6.9 & 8.0 & 1.0 & 0.7 & 0.4 & 2.4 \\
\hline gain $10-19.99 \%$ & 3.4 & 4.0 & 1.7 & 3.9 & 13.2 & 11.9 & 1.4 & 1.2 & 0.0 & 1.1 \\
\hline gain $>=20 \%$ & 1.8 & 1.9 & 0.8 & 1.7 & 39.3 & 38.4 & 1.6 & 1.9 & 0.0 & 0.9 \\
\hline All & 100.0 & 100.0 & 100.0 & 100.0 & 100.0 & 100.0 & 100.0 & 100.0 & 100.0 & 100.0 \\
\hline \multicolumn{11}{|l|}{ Never Married } \\
\hline lose $>=20 \%$ & 0.0 & 0.0 & 0.0 & 0.0 & 0.0 & 0.0 & 0.0 & 0.0 & 0.0 & 0.0 \\
\hline lose $10-19.99 \%$ & 0.0 & 0.0 & 0.1 & 0.0 & 0.1 & 0.0 & 0.0 & 0.0 & 0.0 & 0.0 \\
\hline lose $5-9.99 \%$ & 0.0 & 0.0 & 0.0 & 0.0 & 0.0 & 0.0 & 0.0 & 0.0 & 0.0 & 0.0 \\
\hline lose $<5 \%$ & 0.0 & 0.0 & 0.0 & 0.0 & 0.0 & 0.0 & 0.0 & 0.0 & 0.0 & 0.1 \\
\hline no change & 2.3 & 4.1 & 0.0 & 0.0 & 0.0 & 0.0 & 85.1 & 85.2 & 100.0 & 64.5 \\
\hline gain $<5 \%$ & 96.3 & 95.1 & 97.4 & 98.7 & 97.4 & 98.7 & 2.6 & 2.2 & 0.0 & 12.7 \\
\hline gain 5-9.99\% & 0.9 & 0.4 & 2.0 & 0.9 & 2.0 & 0.9 & 1.4 & 1.9 & 0.0 & 9.2 \\
\hline gain $10-19.99 \%$ & 0.3 & 0.2 & 0.3 & 0.3 & 0.3 & 0.3 & 3.2 & 2.5 & 0.0 & 5.5 \\
\hline gain $>=20 \%$ & 0.3 & 0.2 & 0.3 & 0.2 & 0.3 & 0.2 & 7.8 & 8.1 & 0.0 & 8.0 \\
\hline All & 100.0 & 100.0 & 100.0 & 100.0 & 100.0 & 100.0 & 100.0 & 100.0 & 100.0 & 100.0 \\
\hline
\end{tabular}

Source: Authors' tabulations from the Urban Institute's DYNASIM model (runid: 440v2).

Notes: Benefits include both OASI and DI for adults. For married people, we consider spouses' benefits to be shared. 


\section{Table 4. Average Ratio of Lifetime Social Security Benefits to Payroll Tax Contributions by Relative Lifetime Earnings of Spouses (within Lifetime Tax Groups) for Married Persons born 1960 through 1980}

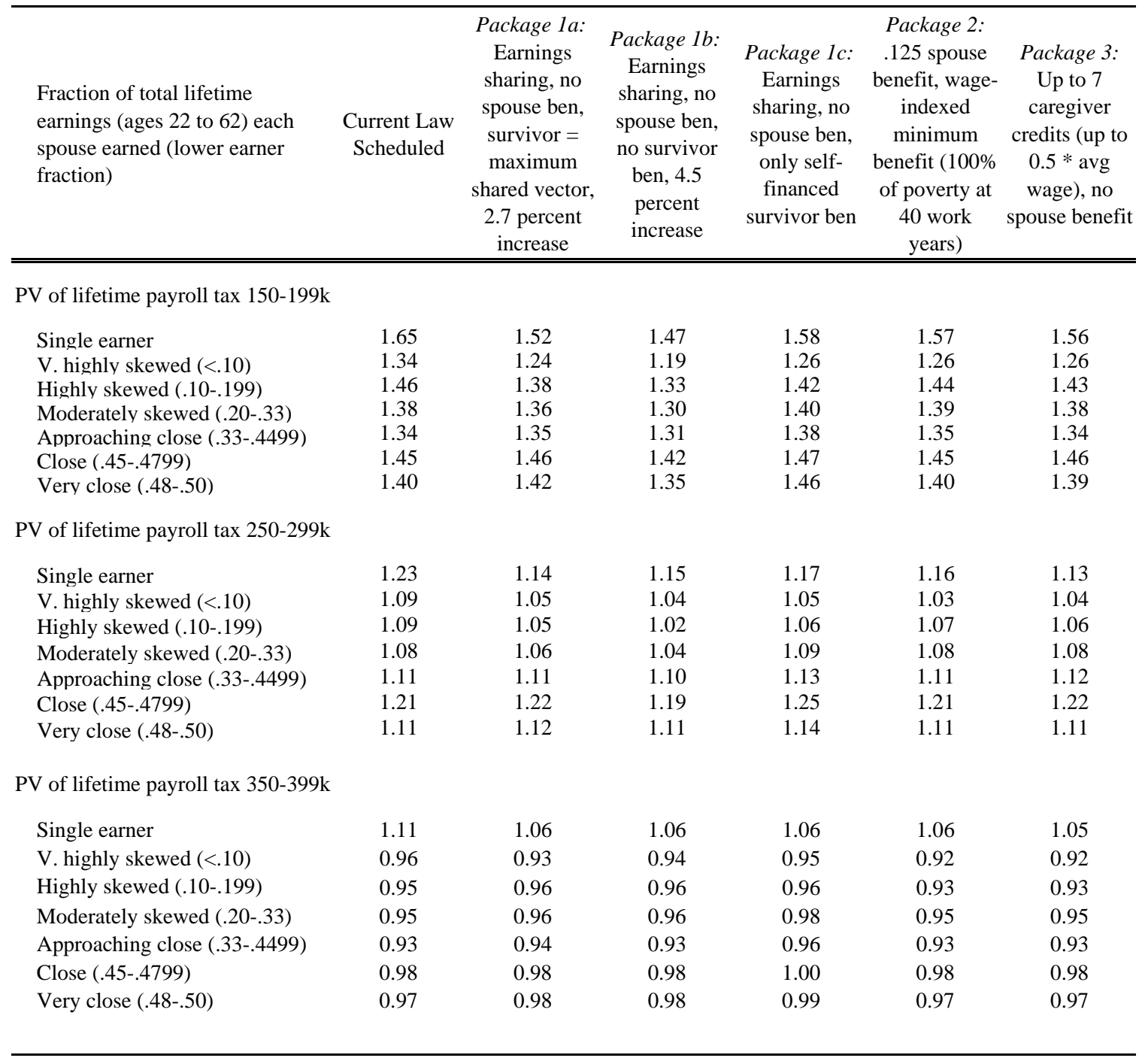

Source: Authors' tabulations from the Urban Institute’s DYNASIM model (runid: 440v2).

Notes: Table includes individuals born 1960 to 1980 who survive to at least age 30. Benefit and tax totals are computed on a couple basis for married people. We apply a discount rate of 2 percent to both taxes and benefits, and evaluate in the year an individual turns 65. Lifetime earnings are defined from age 22 to age 62 (for former spouses, they are defined based on when the beneficiary was 22 to 62 ).

$\mathrm{PV}=$ present value. 


\section{Table 5. Poverty Impacts of the Options: Percent of Adult Current Law Scheduled OASDI Beneficiaries with Income Below Poverty in Year 2049}

\begin{tabular}{|c|c|c|c|c|c|c|}
\hline & $\begin{array}{l}\text { Current Law } \\
\text { Scheduled }\end{array}$ & $\begin{array}{l}\text { Package 1a: } \\
\text { Earnings } \\
\text { sharing, no } \\
\text { spouse ben, } \\
\text { survivor = } \\
\text { maximum } \\
\text { shared vector, } \\
2.7 \text { percent } \\
\text { increase }\end{array}$ & $\begin{array}{l}\text { Package } 1 b \text { : } \\
\text { Earnings } \\
\text { sharing, no } \\
\text { spouse ben, } \\
\text { no survivor } \\
\text { ben, } 4.5 \\
\text { percent } \\
\text { increase }\end{array}$ & $\begin{array}{l}\text { Package 1c: } \\
\text { Earnings } \\
\text { sharing, no } \\
\text { spouse ben, } \\
\text { only self- } \\
\text { financed } \\
\text { survivor ben }\end{array}$ & $\begin{array}{c}\text { Package 2: } \\
.125 \text { spouse } \\
\text { benefit, wage- } \\
\text { indexed } \\
\text { minimum } \\
\text { benefit (100\% } \\
\text { of poverty at } \\
40 \text { work } \\
\text { years) }\end{array}$ & $\begin{array}{l}\text { Package 3: } \\
\text { Up to } 7 \\
\text { caregiver } \\
\text { credits (up to } \\
0.5 * \text { avg } \\
\text { wage), no } \\
\text { spouse benefit }\end{array}$ \\
\hline All Women & 5.43 & 5.16 & 6.01 & 4.88 & 4.98 & 4.87 \\
\hline Married, spouse beneficiary & 1.97 & 1.14 & 1.14 & 1.14 & 1.67 & 1.29 \\
\hline Married, spouse not beneficiary & 3.73 & 3.73 & 3.71 & 3.86 & 3.70 & 3.73 \\
\hline Never married & 8.06 & 7.42 & 7.13 & 7.13 & 6.03 & 5.40 \\
\hline Divorced & 7.83 & 6.23 & 7.10 & 5.95 & 7.65 & 7.03 \\
\hline Widowed & 5.90 & 6.31 & 8.87 & 5.47 & 5.47 & 5.72 \\
\hline All Men & 4.89 & 4.74 & 4.89 & 4.68 & 4.17 & 4.96 \\
\hline All People & 5.17 & 4.96 & 5.48 & 4.79 & 4.59 & 4.91 \\
\hline
\end{tabular}

Source: Authors' tabulations from the Urban Institute's DYNASIM model (runid: 440v2). Notes: Sample includes DI worker beneficiaries ages 25 and older and OASI beneficiaries ages 62 and older. For married couples, benefits are shared. Computations use aged poverty thresholds for both older (age 65+) and younger beneficiaries.

Figure 1. Percentage of Aggregate Social Security Benefits for Adults by Type, 2005 (Excludes DACs)

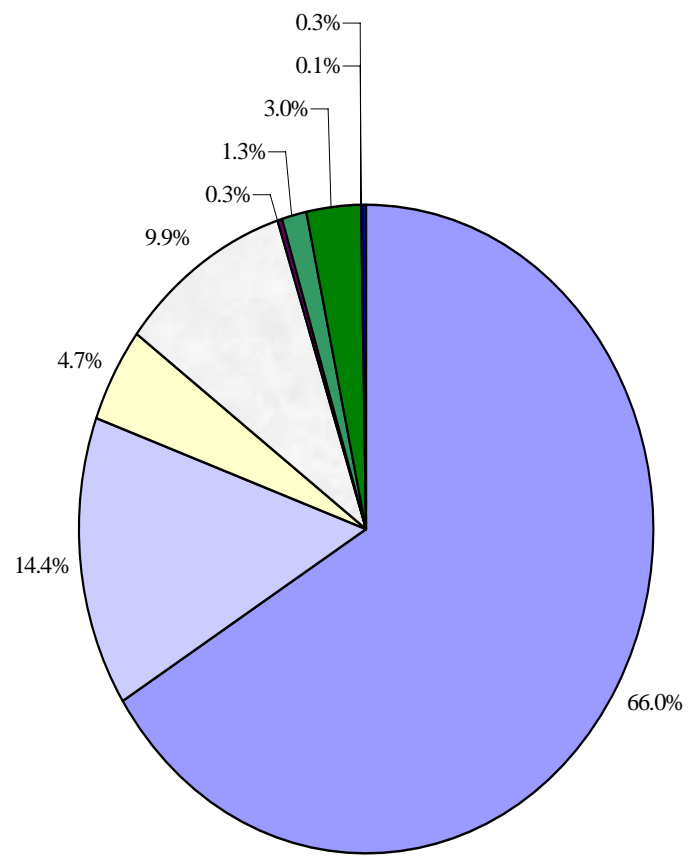

$\square$ Retired workers, incl worker part DEs

$\square$ Disabled workers

$\square$ Dual survivor secondary portion

$\square$ Nondisabled widow(er)s

Disabled widow(er)s

$\square$ Dual spouse secondary portion

Wives and husbands of retired workers

$\square$ Wives and husbands of disabled workers

Mothers and fathers

Source: Authors' calculations based on Tables 5.A16 and 5.G3 from Social Security Administration (2007)

Notes: DE=Dual Entitlees, DACs=Disabled Adult Children 


\section{RECENT WORKING PAPERS FROM THE}

\section{CENTER FOR RETIREMENT RESEARCH AT BOSTON COLLEGE}

\section{How Economic Security Changes During Retirement}

Barbara Butrica, February 2007

International Investment for Retirement Savers: Historical Evidence on Risk and Returns

Gary Burtless, February 2007

Job Changes at Older Ages: Effects on Wages, Benefits, and other Job Attributes Richard W. Johnson and Janette Kawachi, February 2007

Cross-National Comparison of Income and Wealth Status in Retirement: First Results from the Luxembourg Wealth Study (LWS)

Eva Sierminska, Andrea Brandolini and Timothy M. Smeeding, February 2007

Saving and Demographic Change: The Global Dimension

Barry Bosworth and Gabriel Chodorow-Reich, February 2007

The Repeal of the Retirement Earnings Test and the Labor Supply of Older Men Gary V. Engelhardt and Anil Kumar, February 2007

Persistence in Labor Supply and the Response to the Social Security Earnings Test Leora Friedberg and Anthony Webb, December 2006

Annuitized Wealth and Consumption at Older Ages

Barbara A. Butrica and Gordon B.T. Mermin, December 2006

Risk and Reward of International Investing for U.S. Retirement Savers: Historical Evidence

Gary Burtless, December 2006

State Age Protection Laws and the Age Discrimination in Employment Act Joanna Lahey, November 2006

Age, Women, and Hiring: An Experimental Study

Joanna Lahey, November 2006

All working papers are available on the Center for Retirement Research website (http://www.bc.edu/crr) and can be requested by e-mail (crr@bc.edu) or phone (617-552-1762). 